\title{
Present and the Future of British Books
}

This paper, written by the librarian of Queens University, Kingston, Ont., Canada, while the European war was still at its height, pictures conditions which its author now intimates may already be somewhat relieved.

$\mathrm{T}$ HE UNDERDEVELOPMENT of the British book trade has reached a stage at which it becomes the concern of its friends in all countries. "The whole publishing world is topsy-turvy," says an eminent publisher. More than a year ago the president of the board of trade placed a heavy hand upon books, apparently upon the assumption that there were plenty of books already in the country. The annual allocation of paper gave His Majesty's Stationery Office I00,000 tons; left 250,000 tons for the necessary newsprint (which even thus was wofully curtailed); allowed the War Office 25,000 tons; and gave the many periodicals published throughout the United Kingdom 50,000 tons. There remained an amount of 22,000 tons, and this was spared for books. Even the desperate measures that the publishers have taken in using thin paper and exiguous margins have not enabled them to produce a tithe of the prewar publications.

Also, as a result of the destruction of over twenty million stored books by German bombs in 1940 and succeeding years, there is a woful scarcity of the classic works that six years ago were to be found in every bookshop or to be obtained immediately from the publisher. A recent report from one of the largest bookshops in London records the present situation.

We are unable to offer any of the Oxford books of verse. We must refuse enquiries for any lives of Charles Lamb, or for his Letters edited by E. V. Lucas; we have no standard works of natural history, for instance, Witherby's Handbook of British Birds, or Thorburn's British Birds. The few bird books that we have are mainly the "shown to the children" variety. Wyndham Lewis's Pierre Ronsard and Gooch's Courts and Cabinets are sold out and unobtainable. (I'note these as examples that may be many times multiplied.) It is almost impossible to obtain a new standard work on any subject; and, as the supply shrinks, the demand increases.

The secondhand book dealers are in a somewhat better position with regard to their immediate stocks. They can sell almost anything that has topical or literary value, but they are closely hedged by the circumstances of supplies that appear to be running amazingly short. Irish writers in the old days spoke admiringly of "the hosts of the books of Erin," and, before the war, a similar phrase might have been used by any British dealer in books. But now the hosts have either perished or have vanished underground. Private libraries come infrequently to market, although, ironically enough, the salvage drive to obtain worthless books for pulping brought out hundreds of volumes that secondhand dealers now would almost have given their right hands to secure.

With this decline in the number of ex- 
isting books goes a similar reduction in what used to be substantial stocks of paper and of books in sheets. We are told that the number of new books sold by the publishers during the year 1943 exceeded the number printed by almost 50 per cent. With this fact goes another of additional depression-that still existing stocks contain an increasing proportion of books for which there is little or no demand. The publisher, therefore, is rapidly approaching a point at which the books he has in stock are unsalable and the books for which he is asked are unprintable. Thus the present situation is that paper and the prewar stocks of required books have been virtually exhausted.

At the same time, under the stimulus of war, many new voices have sounded in Britain demanding to be heard. There is a great increase in self-expression; there is a new confidence, a feeling that the country has proved herself, and that British ideas and the British way of life are worthy of consideration by the people of other lands. Both publishers and booksellers look out upon a future market that may be described as world-wide. The British dominions are a magnificent field for British books, but the tour of British publishers through Canada in 1943 showed not only that British editions were difficult-and in many cases impossible-to obtain but that the small type and wartime format forced upon publishers by present conditions had operated adversely to England and in favor of books published in the United States. Apart from the possibility of a cooperative agency or a distributing center for books, somewhere on the continent, it is evident that Canada will be swayed, in book purchasing, by her proximity to the United States and by the differences in time for the delivery of orders that are as yet inevitable. With the coming of the freightcarrying airplane after the war, this dif- ference in time may not be so notable, and without doubt there will be a market both in Canada and in Australia for British books. The home market as yet offers demands that cannot be supplied. Books of great variety, in quantities that tend to increase, continue to be required by the armed services. Textbooks to meet the war situation, books for technical training, books for educational courses and for recreational use are ordered to meet an immediate demand. In this case the difficulty is not with paper but with labor. The workers left in the printing industry are almost all above the average age, and four years of war have taken a great toll of these elderly or infirm men. The calls made upon them for patriotic duties (i.e., home guard, civil defense, and firewatching) have further straitened their powers, and now the government is asked to allow a small number of men of military age to be deferred in calling up or to allow a release from military service of an additional few. Even here the severest pinch is not felt. It is in binding, where the shortage of women workers is already acute and has considerably reduced production. The number of learners entering the work is less than one-third of the prewar rate. Many have drifted into occupations which are assumed to be more essential, and now, with the decreasing proportion of younger women entering the limited number of binding firms engaged in book production, hundreds of machines are standing idle. In the first year after the end of hostilities about four thousand additional women workers will be required. Morale is still high and the increasing nervous strain is still being borne; but old age, family responsibilities, and the partial collapse that will come to many after the long strain is ended will seriously deplete the ranks of feminine labor in many industries. 


\section{Need for Educational Books}

These labor difficulties in printing and binding have made the task of maintaining an even flow of supplies to the publisher impossible, and this again accentuates the exasperation of the bookseller when the orders that he knows are in hand appear to remain there indefinitely. In the educational field, also, the difficulties are deplored. In November $1943 \mathrm{H}$. A. Butler admitted that the shortage of textbooks was hampering the schools. Postwar education plans, already being shaped, called for immense supplies of new and progressive textbooks. Colonial governments are already sending to England for large supplies of schoolbooks to make up wartime shortages. The immense new educational projects for Africa alone, to take only one instance, stress the fact that the individual native is prepared to buy books. Schools in the Gold Coast, in Kenya, and in Sierra Leone, are indicating a demand that is very great, and, "generally speaking, a plan for local production does not exist."

The need for technical books of all kinds increases to desperation. With the end of the war in Europe, the need for books on building, on architecture, and on woodwork will become pressing. The demands for books on economics and sociology, for books on foreign languages (especially Russian), for books upon current trends in history and on postwar problems, for books on horticulture and country life, and, perhaps above all, for the Bible, prayer books, and hymnbooks, are and have been for many months unsatisfied and insatiable. The number of juvenile readers has enormously increased. Libraries throughout the country have been advertising "children's book weeks," and the heightening of normal demands in particular localities where these book weeks have been held is such that many publishers now refuse to accept orders for popular children's books.
It is perhaps necessary also to mention the shortage in the number of medical books. The demands of the state have greatly increased in this branch of publishing, but the publisher's quota of paper has not been increased to match.

The destruction of the special paper required in Bibles has also raised a problem that is yet insuperable. The present straw papers cannot worthily be used to print the book whose flawless production has so long been the pride of British publishers. The answer to this particular problem must be esparto grass, and one of the first recommendations of the Publishers Association is that steps be taken immediately to reorganize the collection of esparto in North Africa.

As no shipping is required for the production of the present papers, in which straw plays a large part, it is to be expected that the paper quota will soon be increased. This will allow larger editions to be printed and will enable the exports to be increased in quantity. This is not to assert that British publishers are satisfied with the present quality of papers, but that they are prepared to continue, insofar as their ability lies, to put their best foot forward in manufacture while hoping for a change in conditions that will enable the excellent prewar standard papers to be once more obtained.

\section{The Trade Will Arise Again}

The lifting of restrictions upon labor, the reintroduction of young women into the binding bottleneck, the abating of the Stationery Office demands-which now ride the printing trade like the Old Man of the Sea-such immediate measures will enable the publishing trade to regain its feet, if nothing more. The next step must be to turn into print books for which there is an assured demand, and then to register the workers in photolithographic book production. The replacement of machinery 
must also be an immediate consideration.

There is no doubt that the afterwar organization of British publishers will have a strength, a unity, and a direction that was lacking in 1939. The book center which is now in existence, although it is used at the moment only by comparatively few publishers, will undoubtedly continue to attract more firms to its nucleus, since it can attend to all the packing, invoicing, dispatching, and distribution of various publications. In this center also is the reorganised firm of Simpkin, Marshall, Hamilton, Kent, \& Co., Ltd., the long-established wholesale house, beginning a new and progressive life.

Even now many books are being published and many plans are being laid for the immediate resumption of a free and vigorous publishing campaign as soon as postwar conditions will allow it. This campaign will be directed, in the first place, to the satisfaction of demands that are certain to come from the continent of Europe. After 1918 British and American libraries contributed largely to place the more important continental French and Belgian collections upon a working basis. Again those collections have been destroyed, and again we must expect a hunger for books that will need to be assuaged. But now conditions prevail in England that were not felt at the end of the last war: the loss of over twenty million new books, the destruction of many old libraries by bombs, the great need for books that is felt by the English people-all will militate against the possibility of large and generously given assistance to Louvain and similar continental libraries. But British people will certainly expect, and British publishers endeavor to make, the offer of a contribution of some magnitude. The only method by which this contribution can be achieved is the issuing of new and wellprinted editions of the great English literature and of European classics.

Beyond a doubt there will be a desire on the part of the peoples of Europe to read English books. The market is waiting, but the conditions that prevail at present in the printing and publishing businesses interpose a barrier of regulations and restrictions behind which publishers can only plan and fret. Whether the Canadian market also is recoverable appears to be in doubt. At any rate, markets there must be, and also a willingness on the part of United States publishers to "live and help live," if the much-battered publishing trade of Great Britain, now on its feet, is to make real progress in a new day. 